\title{
De europceiske inversioner - og Nordatlantens åbning
}

Søren B. Nielsen, Erik Thomsen, David L. Egholm og Ole R. Clausen, Geologisk Institut, Aarhus Universitet

Geologiske processer i de områder, hvor jordskorpens plader møder hinanden og vekselvirker, er ofte meget voldsomme og destruktive. Det kan derfor været vanskeligt at opnå viden om, hvilke kræfter der satte en given udvikling i gang, og om hvornår det præcist skete.

I nylige publikationer i tidsskriftet Nature (Nielsen et al.,2005, 2007) har vi foreslået, at en første voldsom og hovedsageligt sideværts forkastningsbevægelse i forbindelse med Nordatlantens åbning i PaleocænEocæn kunne mærkes som en pludselig spændingsændring for $\sim 62$ mio. år siden i det indre af den europæiske kontinentale plade. Denne spændingsændring markerede ophøret af den sen-kretassiske kompression af det europæiske kontinent.

\section{Inversion}

Inde i den europæiske kontinentale plade har der gennem sen Kridt og Kænozoikum forekommet lokaliserede vertikale bevægelser, som betegnes "inversion”. Navnet skyldes, at der er tale om hævning og erosion af de centrale dele af, hvad der engang var en rift eller et bassin. Den vertikale bevægelse har således i inversionsfasen den modsatte retning af, hvad den havde engang, hvilket også ses i en karakteristisk revers aktivering af gamle normale forkastninger. Et eksempel, der umiddelbart kan iagttages, er højdedraget (Rommelåsen) som strækker sig fra Kullen mod sydøst gennem Skåne. Denne synlige topografi viser blot en lille del af den inverterede Sorgenfrei-Tornquist Zone, der strækker sig fra området syd for Norge til Polen (se figuren til højre).

Det har længe været den fremherskende opfattelse (Ziegler, 1987), at inversionsbevægelserne i Europa kan forklares som kompressionsbegivenheder, hovedsageligt som en funktion af Afrikas gradvise bevægelse mod øst og nordover i forbindelse med bl.a. det centrale Atlanterhavs åbning. Begivenhederne har fundet sted i flere koncentrerede faser gennem sen Kridt, og med en markant begivenhed også i midt Paleocæn.

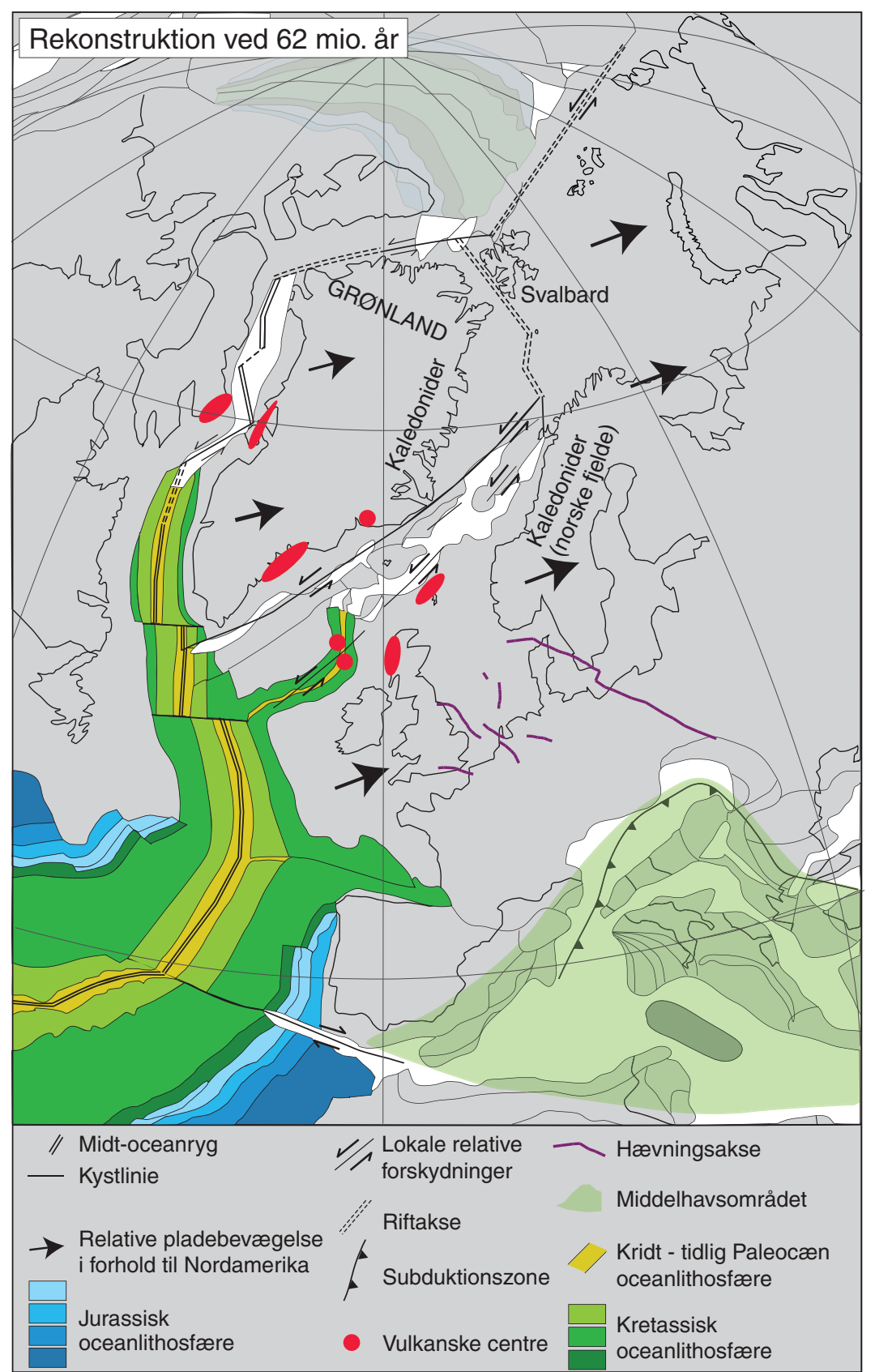

Indtil for ca. 62 mio. år siden hang det nordamerikanske og det europeiske kontinent sammen. Adskillelsen startede med en kraftig nord-syd-forskydning langs med en forkastningszone mellem Norge og Grønland. Forskydelsen forplantede sig formentlig gennem det Arktiske Ocean til Lena-deltatet i Sibirien. (Grafik: Forfatterne)

Netop den midt-paleocæne fase er central for den nye forståelse af de europæiske inversionsbevægelser og deres relation til begivenheder ved pladerandene. Det har nemlig vist sig, at netop denne inversions- begivenhed bedst lader sig forklare (Nielsen et al., 2005) ved en pludselig afslapning af spændingsfeltet i Europa - i modsætning til den etablerede opfattelse, at der skulle have været tale om yderligere en kompres- 
sionsbegivenhed fra Alperne, lig dem der kan forklare de kompressionelt betingede sen Kridt-inversioner langs SorgenfreiTornquist Zonen, det midt-polske trug, i Sydengland, i Nordsøen samt i Holland og dele af Tyskland (fx Harzen) (se figuren på foregående side).

Etableringen af denne første erkendelse i modstrid med den gængse hypotese kan ses i lyset af den naturvidenskabelige proces, som det også er forsøgt gjort med de konkurrerende hypoteser om de norske fjelde (se GeologiskNyt nr. 3/07 samt nærværende nummer). Vores forsøg på at forstå inversionsstrukturernes mekanik ved numerisk modellering (e.g. Hansen et al., 2000; Nielsen and Hansen, 2000) fulgte ganske slavisk det etablerede paradigme om, at kompression var forklaringen på alle inversionsbevægelser. Når forskere således arbejder inden for det etablerede paradigmes rammer, er der i henhold til Kuhn (1970) tale om normalvidenskabelig aktivitet. Denne arbejdsform er en nødvendighed, men den rummer også faldgruber.

\section{Normalvidenskab}

Alment kan siges, at hypoteser samler fortalere og er levedygtige (etablerer sig som paradigmer), fordi de giver udøverne håb om betydelige videnskabelige landvindinger. Hypotesen, dens udøvere, deres metoder, data og fortolkninger betegnes somme tider for en "skole". Det er karakteristisk for mere modne videnskabelige skoler, at de er tilbøjelige til at blive velbehagelige, selvtilfredse og være sig selv nok, formentlig fordi udøverne bliver meget optaget af deres hypoteses succes.

Nye data indsamles for at løse det puslespil, som hypotesen og den udvalgte mængde af relevante data med tilhørende metoder af nødvendighed udgør, og som ligger spredt som sindrige tegn i naturen og blot mangler at blive sat sammen til en smuk og forståelig helhed af dygtige og dedikerede forskere. Med denne puslespilsløsende aktivitet drejer det sig således i mindre grad om den modne hypoteses eksistensberettigelse, men nærmere om yderligere at artikulere hypotesen og at udstrække dens gyldighed - i geologi for eksempel til nye lokaliteter og aldre. I denne fase af den videnskabelige proces - den normalvidenskabelige fase - har skolens medlemmer for længst etableret et fælles sprog og dermed en fælles forståelse af grundlæggende sandheder, som ikke længere behøver at blive bekræftet ( $f x$ at en kompressionspuls må der til for at lave inversion). Dette fælles fundament overleveres i et arvegods af referenceværker og lokaliteter/eksperimenter/observationer. Det er så at sige givet a priori og udgør det selvfølgelige grundlag for nye medlemmers dannelse $\mathrm{fx}$ gennem veldefinerede phdprojekter, der designes til at finde den rette plads til endnu en omhyggeligt afgrænset brik i puslespillet.
Det er vigtigt at understrege, at det er i denne tilstand af normalvidenskab vi alle tilbringer det hele eller det meste at vort forskerliv, og at det er aldeles normalt og fuldstændig legalt og slet ikke noget, man skal beklage. Uden antagelse af en hypotese og den metode- og tankemæssige determinisme, der uvægerligt følger med som bagage, er det umuligt at vide, hvilke data man skal indsamle, eller hvor man skal gå hen for at gøre det.

\section{En lille korrektion til paradigmet}

Således indfanget af paradigmet om at kompression må der til for at forklare alle inversionsbevægelser i Europa gennem sen Kridt og Kænozoikum, gik vi i gang med numerisk modellering og fandt, at det så alt sammen såre godt ud: Modellerne var på det nydeligste i stand til at reproducere observerede geologiske inversionsstrukturer under kompression. Den midt-paleocæne fase røg her med i købet; vi skelnede på dette tidspunkt ikke detaljeret mellem kompressionsfaserne, men anvendte typisk en lang model-kompression fra 80 til 60 mio. år og fik vellignende inversionsstrukturer ud af det.

Vi var i den grad forførte af paradigmet og vore modellers succe, at vores opmærksomhed blev sløvet til at ignorere det forhold, at når vi i modellerne holdt op med at komprimere, dvs. de modelgenererede spændinger fik lov at slappe af, men modellen blev kørt videre på computeren, ja så skete der faktisk yderligere inversion, men ved en anden mekanisme (fleksur) end kompressionsbetinget forkortning af skorpen.

Men en skønne dag blev det pludselig påtrængende at den midt-paleocæne inversionsfase i nyere undersøgelser af en række af hinanden uafhængige iagttagere blev beskrevet ganske anderledes end sen Kridtfaserne: Den midt-paleocæne inversion var 
er blevet udlagt som tegn på, at en termisk kappediapir med oprindelse ved kappe-kernegrænsen for ca. 62 mio. år siden var nået op til basis af lithosfæren, hvor den hurtigt udbredte sig under Grønland og de tilgrænsende områder og forårsagede den samtidige vulkanisme i vidt adskilte områder med ekstra tynd lithosfære (kortet på artiklens første side). Måske var diapiren endog den direkte årsag til lithosfærefortyndende riftprocesser som fokuserede magmatismen.

Vores iagttagelse af den pludselige spændingsændring i det europæiske kontinent betyder imidlertid, at vi nu kan sige, at der jo må have eksisteret et kraftigt spændingsfelt forinden. Det er herefter nærliggende at spørge, om ikke det så kunne være dette spændingsfelt i stedet for kappediapiren, som rev lithosfæren i stykker? Det ville passe vældig godt med diverse strukturelle vidnesbyrd fra det nordatlantiske område og med det paleocæne ophør af nord-syd konvergensen mellem Afrika og Europa, om spændingsændringen blev udløst ved et venstre-lateralt ryk gennem Nordatlanten over det Arktiske Ocean til Lena-deltaet på den sibiriske kontinentalsokkel (kort på side 4).

Dette ryk, som formentlig blot var på nogle få kilometer, men som skete meget hurtigt, fandt altså sted ca. 6 mio. år, inden det kom til kontinentalt opbrud og oceandannelse i Nordatlanten og i det Ark- tiske Ocean. Den foreslåede forskydning langs forkastningssystemet er ikke stor nok til, at den kan ses i pladetektoniske rekonstruktioner baseret på oceanbundens magnetiske anomalier. Vores sammenkædning af begivenhederne i Nordatlanten med spændingsafslapningen i Europa antyder, at kappediapiren måske ikke var nødvendig for at forårsage Nordatlantens åbning. Den kan selvfølgelig godt have været der alligevel, men den eneste gode grund til at påkalde en kappediapir, er nu måske den omfattende vulkanisme - og måske er det grund nok.

\section{Det videre arbejde}

Ovenstående historie har stadig en række åbne ender. Der er jo selvfølgelig spørgsmålet, om det overhovedet er rigtigt, for der er jo blot tale en hypotese, om hvilken man dog kan sige, at den tilfører geologiske begivenheder omkring 62 mio. år lidt mere orden ved at anbringe ganske forskelligartede processer i en pladetektonisk årsagssammenhæng. Derudover sker der netop i sen Kridt-Paleocæn rift-relateret bassindannelse i Østasien (langs den subduktionsaktive kinesiske margin), og det er et interessant spørgsmål, om der kan være en sammenhæng, der jo i så fald bliver nærmest global. Det ville være pladetektonisk teoretisk muligt, men ganske enestående, at forbinde så fjerne begivenheder. Nøglen til en sådan forbindelse er etablering af begivenhedernes præcise rækkefølge og eventuel samtidighed ved hjælp af biostratigrafi, fulgt op af numerisk modellering af det fysiske system.

\section{Referencer:}

Hansen, D. L., Nielsen, S. B. \& Lykke-Andersen, H., 2000. The post-Triassic evolution of the Sorgenfrei-Tornquist Zone - results from thermo mechanical modelling. Tectonophysics 328, 245-267.

Kuhn,T., 1970. The Structure of Scientific Revolutions. The University of Chicago Press, Chicago, 210 pp.

Nielsen, S. B. \& Hansen, D. L. , 2000.

Physical explanation of the formation and evolution of inversion zones and marginal troughs. Geology 28, 875-878.

Nielsen, S.B., Thomsen, E., Hansen, D.L. and Clausen, O.R., 2005. Plate-wide stress relaxation explains European Paleocene basin inversions. Nature, 435, 195-198. Nielsen, S.B., Stephenson, R.A., and Thomsen, E., 2007. Dynamics of mid-Paleocene North Atlantic rifting linked with European Paleocene intra-plate deformations. Nature 450, 1071-1074.

Ziegler, P.A. , 1987. Late Cretaceous and Cenozoic intra-plate compressional deformations in the Alpine foreland - a geodynamic model. Tectonophysics 137, 389-420.

\section{Kort nyt}

\section{Vulkanudbrud i Chile}

13 år efter vulkanen Lliamas sidste udbrud begyndte den omkring årsskiftet igen at udspy røg og flammer. Lliama betragtes som Chiles største slumrende vulkan. 150 mennesker i lokalområdet blev straks efter udbruddet evakueret.

$J P / S L J$

\section{Jordskælv i Mexico}

USA's geologiske overvågningsinstitut oplyser, at et jordskælv med en styrke på 5,4 på Richterskalaen d. 8. februar rystede et område tæt på den nordmexicanske by Mexicali med omkring en million indbyggere. Skælvets epicenter lå kun 26 km syd for byen, men det forårsagede umiddelbart ingen materielle ødelæggelser.

Jordskælvet kunne mærkes i det sydlige Arizona og Californien. 